\title{
A discourse of Nigerian Urban Developmental Projects in Lagos State
}

Abosede Olubukola Akindele, ${ }^{1 *}$ Dorcas Oluwaseyi Adeoye,${ }^{2}$ Olanrewaju Waheed Abass ${ }^{3}$ and Funmilayo Adebola Bashua $^{1}$

1. Department of Architecture, College of Environmental Sciences and Management, Caleb University, Imota, Lagos State, Nigeria.

2. Department of Architecture, Ladoke Akintola University of Technology, Ogbomoso, Nigeria

3. Department of Building Technology, School of Environmental Studies, Yaba College of Technology, Yaba, Lagos, Nigeria.

* E-mail of the corresponding author: dorcasolu2010@gmail.com

\begin{abstract}
This paper presents a discourse on infrastructural development in housing and urban schemes in Lagos state, Nigeria. It focuses on urban governance, critical statistics, impacts of urban development and planning in decision making. Also, factors affecting housing and urban development processes were discussed. Government policies aids in urban growth were also examined in order to bring a change process for the leading actors. In order to achieve the desired goals in the urban and housing development in Nigeria, especially Lagos, suggestions were outlined to make urban housing industry acceptable for both men and women actors.
\end{abstract}

Keywords: Infrastructures, governance, policy, urban, development, planning

DOI: $10.7176 / \mathrm{ADS} / 80-07$

Publication date: January $31^{\text {st }} 2020$

\section{Introduction}

Urban Governance and adequate urban infrastructure among others are two major key indicators of good urban governance in the less developed countries cities. Competent delivery of governance, leadership and management relating to urban infrastructure is essential and critical which must be taken seriously according to Otegbulu (2013). There has been so much investment in infrastructure development in Lagos state which affirms that despite all the investment by the government yet there is a wide gap between public desires and government policy with respect to urban governance (Otegbulu, 2013). There is not much to be shown in ground in most Third World countries like Nigeria. In spite of this, cities in less developed countries are growing at unprecedented rates. Otegbulu, (2013) further identifies the issue of low infrastructure development to tiers of government which are struggling to cope with the pace of urbanization and there is an ever-increasing demand for infrastructure services leading to lack of urban governance management. These infrastructures include water and sanitation, roads, power supply, drainage, waste collection and schools. In view of Nigeria Urban settlement, Lagos state in particular, the demand for services far outstrips the capacity to supply. Infrastructure deficiencies seriously constrain the productivity of private investments in most areas within the state, as firms must invest a good proportion of their capital on private electric power generator. An obvious fact about our bad governance is that of road infrastructure which has led to traffic congestion that impedes the movement of goods and services and thus reduces the economics of agglomeration of Lagos markets. Traffic congestion and unreliable water supply in the statealso constrains manufacturing and households' activities. During and after the former Governor of Lagos state "Ambode administration"(2015-2019) there have been inadequate public collection and disposal of solid waste adding to the deterioration of air, water and land (Figure 1).
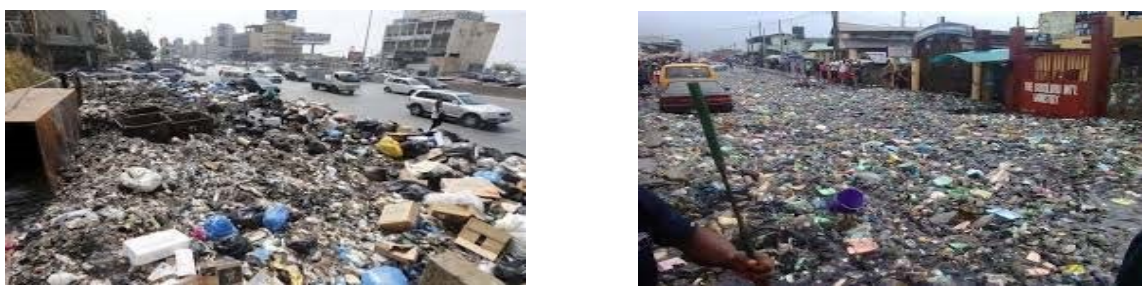

Figure 1: Heaps of indiscriminate refuse along. Lagos streets, pre-1999 http://www.nairaland.com/2425837/photos-wouldnt-believestreet-lagos 
Vivien and Jean-Philippe, (2003); Lyonnareder, (1998) cited in (Otegbulu, 2013) recommends that Lagos state public infrastructure services constitute needed intermediate inputs to economic activities, However, when such services are not available, private enterprises and households are forced to provide them on their own and most times from informal sources. This could be expensive as the poor pay higher prices for services from informal and nonstandard infrastructural providers. They buy water from tankers at prices higher than that charged per litre by water utilities and use wood or charcoal and kerosene for heating and cooking even though the cost per kilowatt hour of these inputs is higher than that of electricity (Lyonnareder, 1998 cited in Otegbulu, 2013). In addition, the poor spends a lot to cope with the low quality of the services from their utility providers. For instance, they purchase storage tanks to compensate for intermittent water shortage. The (the poor) are more often willing to pay more for services than the utilities charge. However, the problem here is that despite of paying more; the quality of services provided may be very poor.

\section{Housing and Urban Development}

Housing according to Oduwaye, (2009) is a social function that transcends beyond the traditional functions of human habitation to include the provision of security, privacy, protection and social status to the owner. The fundamental function of housing cannot be underemphasized. Kabir and Bustani, (2008) noted that housing in general terms shows a critical component in the social and economic structures and constitutes one of the basic human needs of all nations. Ademiluyi and Raji (2008) believed that among the necessary and important items of human need in life is housing, they further add that housing is a priority for the attainment of living standard and it is core to environment either in rural or urban settlements. That being said, one could add that the somatic features of a house often depends on the area's climate, the surrounding terrain, the available building materials and the technological know-how of the builders. In an attempt to provide shelter for its citizens; several housing schemes in Nigeria embarked upon by government and private corporations at various levels have evolved over the years; yet, housing problems have become persistent especially for public servants in the country. Housing in Lagos State, to Adebamowo, (2011), is obviously inadequate both quantitatively and qualitatively. Although Ademiluyi and Raji, (2008) argue and maintained that in most of Lagos state urban centres; problems related to housing is not only circumscribed to quantity but to the poor quality of available housing units, the result of which is manifested in overcrowding in houses as well as increasing pressure on available infrastructural facilities. Historically back to the year 1976, this is about 45 years now in year 2021, as at then it was estimated that about 111,000 residential buildings were available in Lagos to provide accommodation for 3.2million people, which amount to an average of 28.8 persons per building! Data obtained from a survey by Adebamowo, (2011) noted that in the year 1980, the rate of occupancy in Lagos state grew poorer to about 30 persons per building. It was further estimated that only $2 \%$ of the existing population are accommodated in self-contained buildings with 98\% living in "rooming" type of houses. Adebamowo, (2011) also affirmed that Lagos State housing deficit is estimated as 17 million units and it has been projected that Lagos Metropolis would require about 40,000 housing units yearly (estimated at \$1 billion yearly) to accommodate its rising population. Presently, in the Nation; a deficit of 16 million to 22 million housing units is observed, but this figure has created a division between the State government to the Federal Government and Minister of Works and Housing. The housing deficit in the country which is within the range of 16 million and 22 million is unacceptably high. The chairman of Federal Mortgage Bank of Nigeria revealed that the housing deficit in the country stood at 17 million but that of the minister is yet to known by the public. However, the former Governor of Lagos state disagreed stating that the figures of the deficit hadn't been ascertained. Conclusively, whatever value it is, the housing deficit is unacceptably high. It is for this reason that the government is determined to provide affordable housing as a strategic imperative to guarantee the wellbeing of Nigerians. On the contrary; Fashola (2020) in the business news magazine insisted that there are houses available but no one is occupying the apartments. He stated that the housing deficit was more experienced in urban areas than what was recorded in rural areas. He said that it does not mean that there are no houses available to occupy. He further clarifies that the estate which was inaugurated by him, has 154 housing units comprising 80 units of two-bedroom semi-detached bungalows and 74 units of three-bedroom detached bungalows. The construction of the estate was in two phases. For the time being, Nigeria has continued to face housing problems as the shortfall is being recorded in the face of rising population and costly apartments. According to a new report, Nigeria has a deficit of 16 million to 22 million housing units. The deficit has become a cause for concern among Nigerians as the gap between demand and supply widens. Apart from the fact that several Nigerians find it difficult to get a roof over their heads, experts urged the Federal Government to address the housing deficit menace. 


\section{Conceptual and Theoretical Overview}

\subsection{Conceptual Overview}

Urban: Urban is a term that describes a large city. It is viewed as an area with a large number of people residing in it., an area that has been significantly developed, or an area where the distance between buildings is very small. Urban is used in contrast to rural which generally indicates a low population, often agricultural based area.

Governance: Generally governance involves establishment of policies, and continuous monitoring of their proper implementation, by the members of the governing body of an organization. It includes the mechanism required to balance the powers of the members with the associated accountability, and their primary duty of enhancing the prosperity and viability of the organization. Machiavelli, (2003) viewed governance as a broader term than government when he pointed out that government is one of the institutions involved in governance. He gave a wider perspective of governance as the various ways through which social life is coordinated. He noted that the principal modes of governance are market, hierarchies and network. In its wider usage, governance reflects a blurring of the state from the society resulting from changes such as development of new forms of public management; the growth of public/private partnership, the increasing importance of policy network and the greater impact of multi-level government. While some scholars associate governance with a shift away from command and control mechanism, to a reliance on consultation, others argue that it implies preference for 'less government' and a 'free market. (Heywood A. 2002).

Urban Governance: Urban governance refers to an enabling environment which requires adequate legal framework, efficient political, managerial and administrative processes put in place to enable local governments respond to the needs of the citizens. It can thus be defined as the many ways the institutions and the individuals organize the day to day management of a city, and the process used for effectively realizing the short term agenda for the development of a city. UN Habitat, (2012) describes urban governance as the "software that enables the urban hardware to function". Effective urban governance is therefore characterized by democratic and inclusive, long term and integrated, multi-scale, multi-level, territorial, proficient and conscious of digital age.

Urbanization: Urbanization as used in this paper to describes the process by which cities grow or by which societies become more urban. It also means the process by which more and more people leave the countryside to leave in cities. The term 'urban' has generated more controversy in the literature and involves economic, sociological, psychological, ethnic, racial, and numerical dimensions (Aluko, 2010). Urbanization is the physical growth of rural or natural land into urban areas as a result of immigration to an existing urban area. The impact of rapid population growth on urban development and conditions is far more than merely a demographic or quantitative one. According to Otegbulu(2013), urbanization has been the leading demographic trend for some centuries now particularly in nations like Nigeria striving in its development. The factors that drive urbanism is the growth in the economy of any nation. Also, human habitat plays significant role in shaping urbanization. According to Aluko (2010), the urbanization process in the developed countries was the result of rapid industrialization. The urbanization in Nigeria like most other developing nations is a consequence of the "push" of the rural areas and the "pull" of the town. It is essential to note that environmental dilapidation pose so much danger on urbanization.(Enserink and Koppenjan, 2007) cited in Otegbulu(2013) affirms that environmental poverty is greatly measured as direct effect of urbanization process Economic development, population pressure, poor quality of work and rapid urbanization result in the lack of infrastructure, congested traffic, environmental degradation and housing shortage; a major issue faced by cities and towns in their sustainable development. This means that there is an urgent need for good urban governance and management for efficient infrastructure delivery. $\quad$ From the aforementioned related issues which pose a great challenge to urbanization thereby demanding an urgent attention for good urban governance, and therefore, underlines the role of local political leadership in all zones within Lagos state. Governor of the State, House of Representatives, Local government chairmen, councilors and other political leaders, community leaders -have a great role to play in achieving compromises among the diverse interests involved in large and densely populated areas. The whole notion of the subject is central to urban governance. This arises from the fact that issues of governance and basic service delivery determine the morphology of the city, its nature, form and characteristics.

\subsection{Theoretical Overview}

Urban Governance: Urban governance can be explained and understood from the point of view of Associative Network (AN) model. Irazebel, (2004) revealed that in many American and Latin American cities, urban 
governance and planning are either in urgent need for reforms or are undergoing some reforms. However, the inability of some cities to develop their civil capacity has hampered the implementation of reforms i.e., the capacity to build and maintain broad social and political multi-sectoral coalition in pursuit of common goals. Thus, because of varying political and socio-cultural dilemma in time and space, it became logical for urban governance analyst to develop different models that attempt to interpret and provide normative guideline for such complex process within the geopolitical and socio-cultural orientations. Some models were therefore developed in America and Latin America. One of such models referred to as Associative Network (AN) is considered handy for the explanation and understanding of the issues around urban governance. Chalmers (1997) used the term Associative Network to mean the way in which the structure of the society is represented as nonhierarchical act of association. According to him, the structure differs from the two major principles of modern, social and political organization: hierarchies with their relations of authority and dependency. In the associative network model, the term network characterizes purposeful, interconnectedness of social groups that shape public decision and policy without making the assumptions of the nature of the norms guiding the participants' interactions. Associative Network (AN) is therefore defined as a non-hierarchical structure formed through decisions by multiple actors who come together to shape public policy. It is however important to note that the growth of associative network is not the growth of the civil society, but the growth of its connections with the state. As part of the norms of Associative Network, there is possibility for more discussion and deliberative democracy, it is characterized by diversity of organizations, individuals and other participants; there is also room for periodic reconfiguration of the network as issues, decision making rules, participants and opportunities change. The AN lays strong emphasis on cognitive politics, involving debate and discussions of preferences, understandings and claims. Another very important feature peculiar to third world countries is that while ordinarily, ANs often involve actors with sharply unequal resources, there are likely more changes to avoid direct test of strength with an unequal competitor in the third world countries largely due to the following:

i. Lesser emphasis on importance of rigid hierarchies and authority relations among actors in the less developed countries

ii. $\quad$ shifting and multiple identities

iii. more open-ended character of cognitive politics

Chalmers (1997) noted that this model of urban governance can achieve progress by establishing relative state and effective governance, helping overcame drastic inequality in the third world countries and create spaces for effective participation. However, the following conditions are required to achieve the above progress:

i. Organization and procedures that co-ordinate the multiple decision centres, and constantly changing networks.

ii. A framework of rights that make participation in associative network possible

iii. Adopt popular sector strategies that make the most of the opportunities and avoid the pitfalls.

Some of these features can be achieved through appropriate legislation, but a full realization will largely depend on changing values, norms and beliefs; implying changing tradition and producing new issue and contests among citizens, government and planning officials. This may call for enactment of new legislations and laws. Irazabel,(2004) exemplified this in Latin America when he noted that the new experience of participatory urban planning is supported by new enabling legal framework made possible by the struggle of social movement agitating for democratization of government at the local level. It is argued that such level of participation will help minimize clientelism, patronage, neo populism and other practices of hegemonic politics.

\section{Urban Development Policy}

The National Urban Development Policy came into existence as a result of varied complexity created by the rapidly growing Nigerian towns and cities, with the population doubling in almost three to four decades thereby over-stretching the existing facilities (Aluko, 2010). That is, with a growth rate of 2.8 percent, Nigeria has a very high population growth. This results in overcrowding, increased pressure on infrastructural facilities and is intractable linked with urban development. As expected, the visible and most obvious consequence of this urbanization is the rapid deterioration of housing and living conditions (Kabir and Bustani, 2008).

\subsection{Urban Growth: Lagos State Context}

In the last 20 years, explosive urban growth has continued but has primarily occurred in the southern parts of the city including westward into Ojo; eastward in Eti-Osa (also called the Lekki Peninsula); and increasingly now into Ogun State north of the city and to the northwest of the airport (LSG, 2008). The Lagos State Government 
(2008) reports that in the future, it is predicted that the major growth axes will be to east and the west of the southern parts of the city especially in what are now remote areas like Ojo, Badagry, Ibeju Lekki, and Epe. Growth has already begun to occur on the East side towards Lekki with the introduction of the Lekki Expressway. Presently, if Lagos continues to grow in population density and urbanization, the city currently stands as the 14th largest urban area in the world and is on the crisp of becoming a primary coastal megalopolis. Lagos urban area is home to approximately $33 \%$ of the Lagos State population (Sunday and Ajewole, 2006). Urban development in Lagos is taking place by conversion of coastal wetlands into urbanized communities which is a direct result of urban sprawl. Figure 2 below shows a typical urban system dynamics. If the rate of growth of urbanization continues, the community will be forced to confront impacts on soil erosion, biodiversity, infrastructure demands, polarized demographics, and public health.

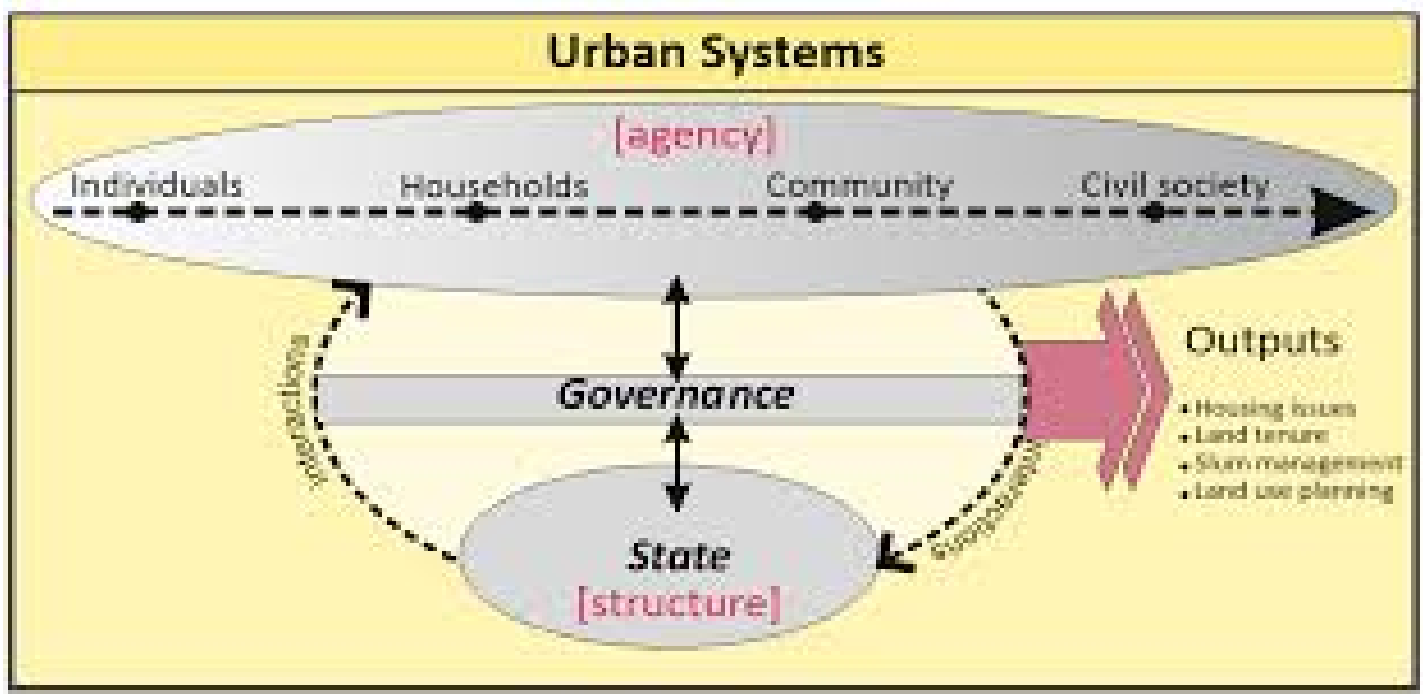

Figure 2: A typical urban system dynamics, Source: Agunbiade and Olajide (2019)

\subsection{Lagos Critical Statistics}

i. Lagos experienced an influx of over 7 million people from 1990 to 2004. In 1990, the population was 7.74 million, which increased to 13.4 million in 2000, and in 2004 population reached up to 15 million. With an urban area population of an estimated 11.7 million, Lagos is the 14th largest urban area in the world. By 2010, the population is projected to surpass 20 million (Ilesanmi 2010).

ii. From 2006-2008, the annual projected growth rate stood at 4.44\%, which had a ranking of the 7 th fastest growing urban area in the world (FGN, 2009).

iii. Lagos has grown spatially from a traditional core settlement of about $3.85 \mathrm{Km}^{2}$ in 1881 to a metropolis of over $1,183 \mathrm{Km}^{2}$. The metropolitan area constitutes about $33 \%$ of Lagos State, with $455 \mathrm{Km}^{2}$ (Akinmoladun, \& Oluwoye, (2007).

iv. When exploring Lagos' importance in Nigeria's national economy, sixty percent of Nigeria's oil industry occurs in Lagos. (Abosede, 2006)

v. With regards to the shipping industry, 80 percent of Nigeria's imports and 70 percent of exports pass through Lagos ports (FGN, 2009).

vi.

\subsection{Causes and Impacts}

\section{Causes:}

i. Conversion from rural to urban area accounts for approximately $75 \%$ of population growth of Lagos' metropolitan area (Akinmoladun, \& Oluwoye, (2007).

ii. Between 1986 and 2002 the developed area in Lagos Coastal Area increased by 13\% (from 43\% in 1986 to $56 \%$ in 2002), while swampland decreased by $11 \%$ and water area decreased by $3 \%$ (Akinmoladun, \& Oluwoye, (2007). 
iii. According to a World Bank Renewal Project, since 1981, the total estimated number of 'blighted-slum' communities has grown from 42 to almost 100, due to a lack of social services and housing development projects (Abosede, 2006).

\section{Impacts:}

i. Urban development in Lagos without conservation strategies has the potential to increase the risk of wetland loss (e.g. creeks, swamps, and lagoons). At the current rate of conversion, the swamps of Lagos will be totally consumed within next 40 years (Sunday and Ajewole 2006).

ii. Soil degradation will alter biogeochemical processes, such as rates of erosion, hydrological flows, and net primary production. Alteration of any of these processes could impact vegetation growth, drinking water quality, and infrastructure sustainability.

iii. Careless urbanization will lead to a biodiversity loss of coastal vegetation and the fish population. An unsustainable fish market would hinder the national the economy as well as international trade.

iv. Alteration of the ecosystem will influence insect habitat and their migration patterns, subsequently increasing the risk of infectious human diseases (Sunday and Ajewole 2006).

\subsection{Urban Governance in Lagos}

According to Agunbiade and Olajide (2019), Lagos has been mostly led by civilian visionary leaders since the creation of Lagos State on May 27th 1967. An important aspect of urban governance in Lagos that has received relatively improved attention is urban management. This has resulted in the ongoing democratisation of the planning process and professionalization of the public sector (Agunbiade and Olajide, 2019). The state government made a commitment to improve urban management and service delivery through the implementation of Performance Management Framework and Service Charters. The central focus of this charter, as described by former Governor Fashola, is to develop a Lagos State that 'will truly be a centre of excellence and Africa's economic hub' (Lagos State Service Charter Policy, 2010) cited in (Agunbiade and Olajide, 2019). All government ministries and other public service providers implement this charter (Agunbiade and Olajide, 2019); it was set up to empower residents to demand for improved services from public authorities. The charter promotes values of adequate service delivery through the adoption of the principles of transparency, accountability and responsiveness. In addition, it improves the public perception of the government and the overall governance situation particularly during Governor Fashola's administration. The gradual evolution of a new public transport system with the emergence of its critical foundational infrastructure is an example that has received global acknowledgement. Although the development initiatives over the past one-and-a-half decades are remarkable, Lagos still faces huge urban challenges. One of the objectives of this research is to explain the drivers of the turn-around considering the short time it has taken to cause a substantial change. In the course of this research, the former Governor Fashola was asked what could be learnt from Lagos' transformation by his government. His response was:

'I don't know really; it is just that I have an undying belief in the capacity of what can happen in this continent. I don't believe that any set of people or race is superior to the other. I realise in the history of human civilisation, it is given to each set of people to redefine their particular era... and so there is no monopoly of developmental capacity.'

Cited in Agunbiade and Olajide (2019)

\subsection{Urban Lagos State Physical Planning Permit Authority (LASPPPA) Agency Responsibilities}

This Authority is saddled with the responsibility of granting building development permit to any applicant who complies with the provision of the Law and the regulations building physical development in Lagos State. Lagos State Physical Planning Permit Authority flow is depicted in Figure 3. Other Functions of the body include but not limited to:

i. Issuance of Planning Permit

ii. Preparation of lower level physical development plans e.g. District Plan, Local Plan and Action Plan.

iii. Monitoring compliance with operative physical development plans in Lagos State.

iv. Keeping records and gazetting of planning permits

v. Probing and Investigation of physical development 


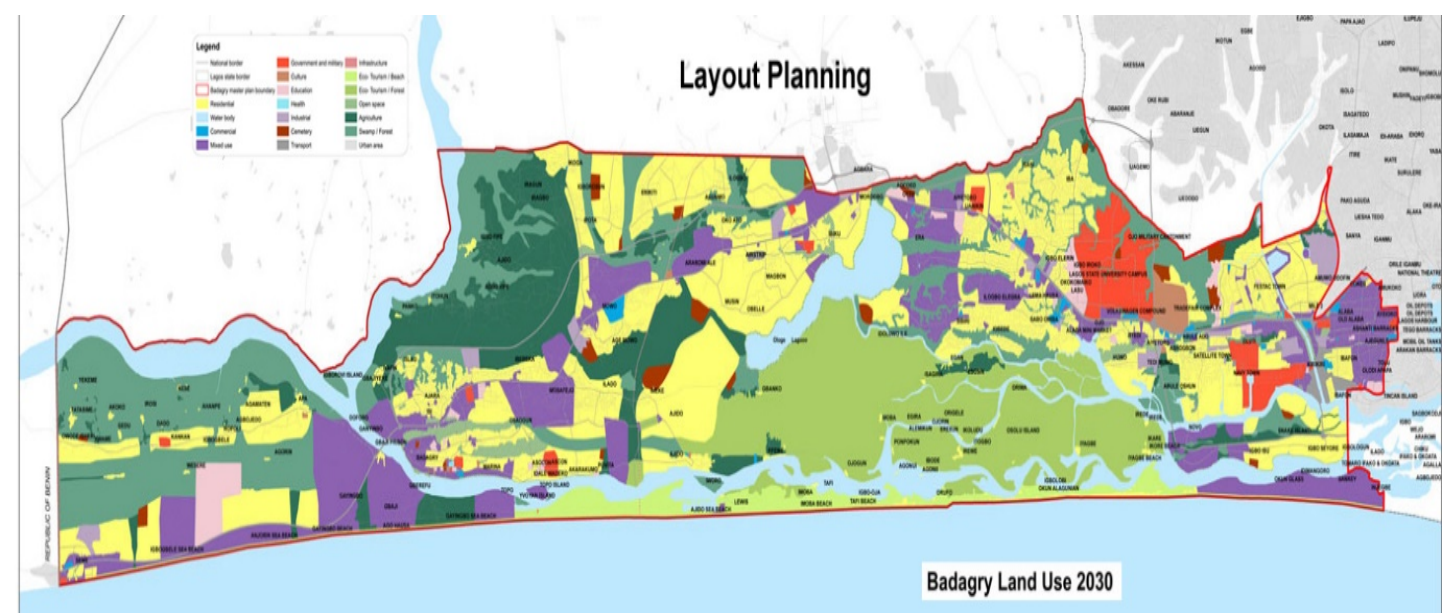

Figure 3: Lagos State Physical Planning Permit Authority

Notwithstanding this undying belief, and the national and international recognition for Lagos State government's turn-around efforts, there are concerns about the extent to which the projects being implemented meet the needs and aspirations of the various socio-economic groups. Also of concern is the institutional and financial capacity to sustain the current turnaround initiatives.

\section{Conclusion}

Nigerians are confronted with a myriad of housing problems, which are essentially connected with the hardships they face in securing and retaining a residence. According to Yusuff (2011), this situation is particularly evident in Lagos state due to the cosmopolitan nature of the state, which has placed great demands not only on housing but also on physical and social amenities, includes: Urbanisation, Population growth rate, Political factor, Project. Financing, Corruption, Limited land Supply, Poverty, Inadequate Planning of the environment, Cost of building materials, Economic state of the nation, Availability of technology and efficient designs, Vandalism, Poor Maintenance culture. All these need to be put into consideration while planning.

\section{References}

Abosede, F. B. (2006). Housing in Lagos Mega City-Improving Livability, Inclusion and Governance. International Conference on Building Nigeria's capacity to implement economic, social and cultural rights: Lessons learned: Challenges and the way forward.(2): 1-11.

Adebamowo, M. A. (2011). The Implication of Global Economic Recession on Sustainable Housing in Lagos Megacity. International Business Research,4 (1): 167 - 176.

Ademiluyi, I., A. \& Raji, B. A. (2008). Public and Private Developers as Agents in Urban Housing Delivery in Sub-Saharan Africa: The Situation in Lagos State. Humanity \& Social Sciences Journal, 3(2): 143-150.

Agunbiade, E. M. \& Olajide O. A. (2019). Urban Governance and Turning African Cities Around: Lagos Case Study: Advancing research excellence for governance and public policy in Afric. Partnership for African Social \& Governance Research, 2016 Nairobi, Kenya. www.pasgr.org

Akinmoladun, O. I. \& Oluwoye, J. O. (2007). An assessment of why the problems of housing shortages persist in developing countries: A case study of Lagos Metropolis, Nigeria. Pakistan Journal of Social Sciences, 4 (4): $589-598$.

Aluko, O. E. (2010). The Impact of Urbanization on Housing Development: The Lagos Experience, Nigeria. Ethiopian Journal of Environmental Studies and Management, 3 (3): 64- 74.

Chalmers J. (1997) Models of Urban Governance and Planning in Latin America and United States: Associationism Regime Theory, and Communicative Actors. Retrieved from http//:www.afro.who.int/news/new-WHO estimate 26 March, 2019.

Federal Government of Nigeria (FGN) (2009). Federal Republic of Nigeria Official Gazette,The Federal Government Printer, Abuja, Nigeria FGP 97/112009/5,000 (OL 67)

Federal Government of Nigeria (FGN) (2010). Draft National Transport Policy. 1-59. 
Heywood A. (2002). Politics. New York: Palgrave Macmillan.

Ilesanmi A.O. (2010) Post -Occupancy Evaluation and Resident's satisfaction with Public Housing in Lagos, Nigeria. Journal of Building Appraisal (6)2:183-169

Irazabal. C. (2004). A Planned city comes of Age: Rethinking Ciudad Guayaba. Journal of Latin American Geography 3(1):22-51

Kabir, B. and Bustani, S.A. (2008). A Review of Housing Delivery Efforts in Nigeria. Retrieved from www.gla.ac.uk/media/media_129767_en.pdf Lagos State Government (LSG) (2008). Lagos Blue Line Urban Rail Concession. Project Briefing Document

Ministry of Physical Planning and Urban Development, (MPPUD) (2012). The Lagos Mega City: Investment Opportunities. 6th Lagos State Economic Summit, Lagos, Nigeria. 1-52

Oduwaye, L. (2009). Challenges of Sustainable Physical Planning and Development in Metropolitan Lagos. Journal of Sustainable Development, II (1), 159 - 172.

Otegbulu. A.C. (2013). Governance and Management of Urban Infrastructure Services in Lagos, Nigeria. Journal of Public Administration and Policy Research 5(1):8-21

Sunday, O. A. and Ajewole, A. I. (2006). Implications of the Changing Pattern of Landover of the Lagos Coastal Area of Nigeria, American-Eurasian Journal of Scientific Research 1 (1): 31-37, 2006 ISSN 1818-6785.

Vivien F. and Jean-Philippe T. (2003). Assessing the Impact of Transport and Energy Infrastructure on Poverty Reduction. Asian Development Bank. Amazon.com 